\title{
Editorial: Digitisation
}

Dermot O'Dwyer BE, MEngSc, PhD, CEng, MIEI, MICE

Associate Professor, Civil, Structural and Environmental Engineering, Trinity

College Dublin, Ireland

Two recent technical developments are facilitating research in the field of engineering history. The first is the ubiquitous internet which puts so much information at our fingertips. Although we have all learned that this information may be of uncertain and unknown quality, the dissemination of misinformation did not start with the internet: many reference books and other secondary printed sources also contain errors. One technique to avoid propagating such errors is to consult primary sources. Luckily, the second major technical development is the digitisation and distribution of a growing number of historic drawings, books, correspondence and other archive material.

Across Europe, America and the wider world the amount of material that is being digitised and made publicly available is increasing by the day. As internet bandwidth has increased and best practice with respect to digitising has matured, high-quality copies of key texts are becoming available and more records are being put in an electronic form that allows the text to be searched. These developments will have a significant impact on research in engineering history in the future. Furthermore, the benefits of digital archives extend beyond those researchers who have the time and money to visit libraries containing the originals.

The availability of high-quality PDF versions of engineering classics, such as Smeaton's treatise on the construction of the Eddystone lighthouse or Provis' account of the construction of Telford's Menai Strait bridge, gives unprecedented access to such works. These texts are large-format publications with highly-detailed drawings, and high-quality digitisations of these texts have now been made available to all courtesy of the e-rara project (http://www.e-rara.ch/). Reading these works and studying the drawings is a real source of pleasure. Fairbairn's description of Stephenson's Britannia Bridge is also now available, via Google books.

In recent years the Institution of Civil Engineers has digitised its proceedings, and these can be searched and accessed via the ICE's virtual library. One can discover what it was like to sit among the audience of evening meetings in the mid-nineteenth century, rubbing shoulders with Stevenson, Barlow, Bidder or Brunel, by downloading at no cost the discussions that followed the papers. Searching under Brunel + Stevenson identifies thirteen discussions where both men contributed.

Many universities and organisations such as the ICE are also uploading digital images from their collection. Medium-resolution images are often free while higher-resolution images may incur a charge.
The ability to capture the details of a book in digital form is also revolutionising the traditional print medium. Those who don't want to read historic books on-screen can now order many historic texts through Amazon, while those who use electronic readers will find that many classic engineering texts, such a Samuel Smiles' Lives of the Engineers, are available to download and read for free. The ICE has also reissued a number of classic engineering works in facsimile form, such as Cresy's classic Encyclopaedia of Civil Engineering of 1861.

This move to digitisation and dissemination is reaching a critical mass and will continue to accelerate. Furthermore, other information, such as the ICE's Panel for Historic Engineering Works (PHEW) database is available online. This database, like many others, is available in the form of a geographical information system (GIS) where the data can be accessed via a map interface.

Ironically, while there are tremendous benefits to digitising existing records, the storage of primary information in electronic form has potential problems in the longer term. It is likely that simple established formats, such as PDF, will continue to be supported but specialist computer-aided drawing (CAD) and building information modelling (BIM) software is much more pragmatic. For commercial reasons there is a financial incentive for companies supplying CAD software to develop and implement new versions incorporating new formats and methods of building CAD drawings. Although CAD is still relatively new there have already been several high-profile projects that have been delayed due to problems arising from incompatibilities between files generated using different software upgrades. Industry's relentless move to computer-based information may well be storing up serious problems for future researchers.

\section{Notes on papers in the present issue}

The papers in this issue of Engineering History and Heritage combine reflections on some great engineering and engineers of the nineteenth century with the challenging job of managing a river system in India designed at a time when the modelling of water flow was not as precise as it is today.

\section{Joseph Locke: pioneer civil engineering project manager}

This fascinating paper by Martin Barnes (2013) compares and contrasts the styles and personalities of Brunel, Stevenson and Locke, who were both contemporaries and friends. Locke was close in age to Robert Stephenson and started his career under Robert's father George. Indeed Locke was the driver of the Rocket on the opening of the Liverpool and Manchester 
Railway, when, through no fault of Locke's, it ran over and killed William Huskisson.

Of the three engineers the author champions Locke as the engineer who tended to deliver projects on time and on budget, and attributes this to Locke's project management skills. Locke's approach, which emphasised 'buildability' over innovation, enabled him to make money for the contractors while simultaneously saving money for the railroad shareholders. He was responsible for the construction of more miles of railway than either of his more famous friends.

\section{The Scottish contribution to New Zealand's lighthouses}

The paper by Guinevere Nalder (2013) demonstrates the far reach of the Industrial British Empire in the latter half of the nineteenth century and early years of the twentieth century. The lighthouses constructed in New Zealand during this period were profoundly influenced by the practices and expertise of Scotland's northern lighthouse board. This situation arose originally because of the close family and work ties between James Balfour, the marine engineer for Otago province and ultimately colonial engineer, and the famous Stevenson firm of lighthouse builders. The close links led to New Zealand adopting the practices of the northern lighthouse board, using the Stevenson firm as consultants and even ordering many stores from Scottish suppliers.

A Norwegian roadmaster's 1838 tour of Britain and beyond The paper by Hans Seland (2013) describes 'Roadmaster Johnson', a Norwegian engineer who took a government sponsored tour of the Baltic countries in 1838 with the purpose of reporting on the transport infrastructure he encountered. Johnson subsequently published a handbook that took the form of an engineering manual. This text is a very good example of technology transfer, which potentially throws new light on some UK projects. The paper looks at the relationship between the Kalemouth Suspension Bridge, south-west of Kelso in Scotland, designed by Samuel Brown and completed in 1830, and Johnson's Norwegian Bakke Bridge completed in 1844.

\section{The restoration of Calver weir, UK}

The final two papers on weirs form an interesting pair. Both deal with river control systems and both have ancient origins, but in terms of location and scale they are in sharp contrast.

The paper by Thornton et al. (2013) describes the restoration of a weir with nearly a thousand years of history. Calver weir in North Derbyshire lies on the River Derwent. The Domesday book of 1086 records a mill at 'Calvoure' but the structure at the heart of the paper was constructed in 1799 and enlarged in 1833. Calver weir is a Grade II listed building but damage to the weir left it in a precarious state in the early 'noughties', so that emergency repairs were necessary in 2004. The maintenance and reinstatement of the weir was important to maintain the upstream marsh and wetland ecosystem that has developed upstream of the weir.
The paper describes the subsequent project to reinstate the weir. The paper will be a great use to others planning to embark on similar projects. The restoration work is described in detail and full account of all aspects of the project, including the financial challenges that were overcome, is given. As with so many heritage projects much of the input to the project was voluntary.

\section{Water resources development in the Cauvery river} basin, India

The final paper, by Stacey and Visweswaran (2013), concerns the development of the complex river control systems in the Cauvery river basin. These systems have their origins in antiquity but the focus of the paper is on developments during the nineteenth century and early twentieth century by engineers such as Captain Caldwell, Colonel Arthur Cotton and Colonel R.J. Sankey. The water flowing through the Cauvery river basin is very important for irrigation in the downstream delta and the paper reflects on the fact that many of these developments were planned on the basis of the incorrect formulae that were in circulation before Darcy and Baxin, Ganguillet and Wilhelm Kutter and, ultimately, Robert Manning developed more appropriate formulae.

In years of plentiful rainfall the systems work to everyone's satisfaction but in dryer years long-running disputes reignite over the available water. The paper briefly considers appropriate strategies for monitoring and modelling the system with a view to optimising the available resources. Unfortunately, climate variation and rising water demand are likely to continue to challenge the engineers who continue to control and manage the Cauvery river basin.

\section{REFERENCES}

Barnes M (2013) Joseph Locke: pioneer civil engineering project manager. Proceedings of the Institution of Civil Engineers Engineering History and Heritage 166(2): 65-72, http://dx. doi.org/10.1680/ehah.12.00008.

Nalder GV (2013) The Scottish contribution to New Zealand's lighthouses. Proceedings of the Institution of Civil Engineers - Engineering History and Heritage 166(2): 73-82, http://dx. doi.org/10.1680/ehah.12.00001.

Seland H (2013) A Norwegian roadmaster's 1838 tour of Britain and beyond. Proceedings of the Institution of Civil Engineers - Engineering History and Heritage 166(2): 8393, http://dx.doi.org/10.1680/ehah.12.00005.

Stacey DB and Visweswaran VR (2013) Water resources development in the Cauvery river basin, India. Proceedings of the Institution of Civil Engineers - Engineering History and Heritage 166(2): 106-118, http://dx.doi.org/10.1680/ ehah.12.00009.

Thornton G, Welsh P, Harris G and Cliff P (2013) The restoration of Calver weir, UK. Proceedings of the Institution of Civil Engineers - Engineering History and Heritage 166(2): 94 105, http://dx.doi.org/10.1680/ehah.11.00021. 